Available online at_www.iponlinejournal.com

\title{
Ectodermal dysplasia diagnosed in dental set up- A case report
}

\section{Shaik Ali Hassan ${ }^{1 *}$, Sumit Bheteja ${ }^{2}$, Geetika Arora ${ }^{3}$}

${ }^{1}$ Dental Surgeon, ${ }^{2} \mathrm{HOD},{ }^{3}$ Reader, ${ }^{2}$ Dept. of Oral Medicine \& Radiology, ${ }^{3}$ Dept. of Public Health Dentistry, ${ }^{\mathbf{1}, 2}$ Manav Rachna

Dental College, Faridabad, Haryana, ${ }^{3}$ Inderprastha Dental College \& Hospital, Ghaziabad, Uttar Pradesh, India

\begin{abstract}
Ectodermal dysplasia is a hereditary disease characterized by dysplasia of tissues of ectodermal origin. This case report discusses the features, diagnosis \& management of such a rare entity in dentistry.
\end{abstract}

Keywords: Ectodermal dysplasia, Hereditary, Anodontia.

\section{Introduction}

The ectodermal dysplasia is a large and heterogeneous group of disorders characterized by a variety of congenital defects in structures of ectodermal origin including skin, hair, teeth, nails, and sweat glands. It has inherited X-linked recessive trait, gene on the $\mathrm{X}$ chromosome in the positions from q13 to $\mathrm{q} 21 .{ }^{1}$ Autosomal dominant and autosomal recessive hypo hidrotic ectodermal dysplasia are caused by mutation in the DL gene, which encodes for the EDA receptor. ${ }^{2}$ There is hypodontia, hypotrichosis, and hypohidrosis. Neonates have excessive scaling of the skin and unexplained pyrexia. Patient's have parse hair and eyebrows. As the patient grows there will be frontal bossing, saddle nose, sunken cheeks, everted lips wrinkled and hyperpigmented skin around the eyes. Patients have fever of unknown origin because of the inability to sweat. In this case a adult is diagnosed with hidrotic ectodermal dysplasia which is a different one as it is most often seen in the children.

\section{Case Report}

Patient came to department of oral medicine and radiology with the chief compliant of missing anterior teeth in both maxillary and mandibular region. Patient also gave a history that no extraction or exfoliation was done but still the teeth were missing. Then she was asked for family history, which revealed that his sister and suffering from this condition. Patient also said that thee was dry skin and no sweat. Patient also told about the dry mouth. On extraoral examination there were scanty eyebrows and eyelids, frontal bossing, dry facial skin (Fig. 2), scalp hair was Soft, dawny, darker in colour, dystrophic nails (Fig. 3).

On intraoral examination it revealed missing anterior tooth in maxillary and mandibular anterior teeth (Fig. 1), with high arch palate was seen. All the findings from above intraoral and extraoral reveals that is hidrotic ectodermal dysplasia.

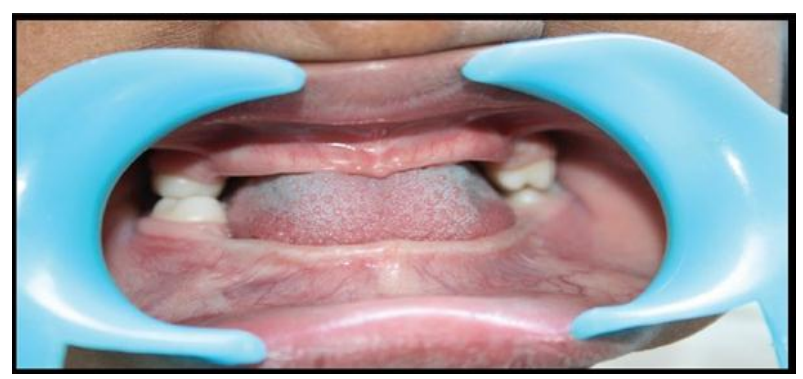

Fig. 1: Intraoral picture

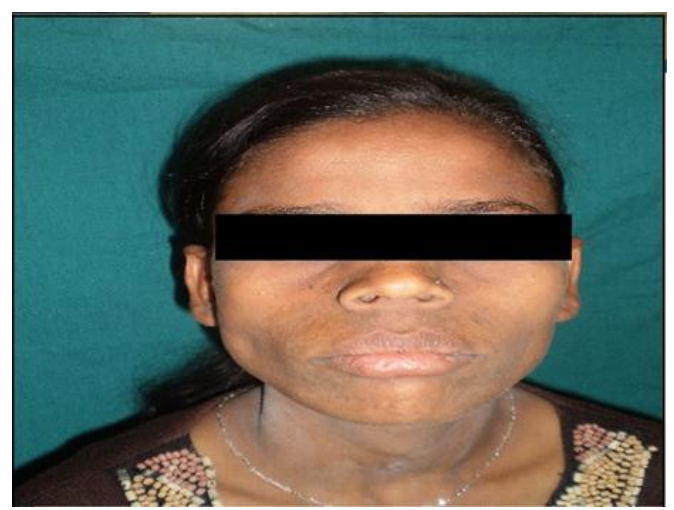

Fig. 2: Extraoral picture of patient

\footnotetext{
*Corresponding Author: Shaik Ali Hassan, Manav Rachna Dental College, Faridabad, Haryana, India Email: alishaikhassan@gmail.com
} 


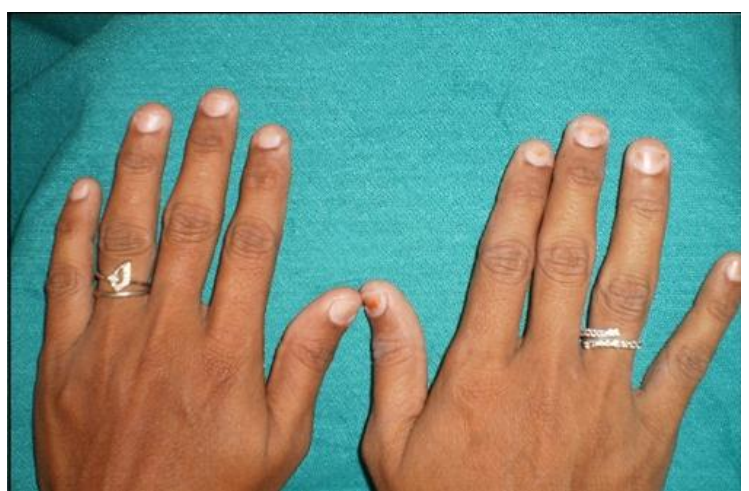

Fig. 3: Dystrophic nails

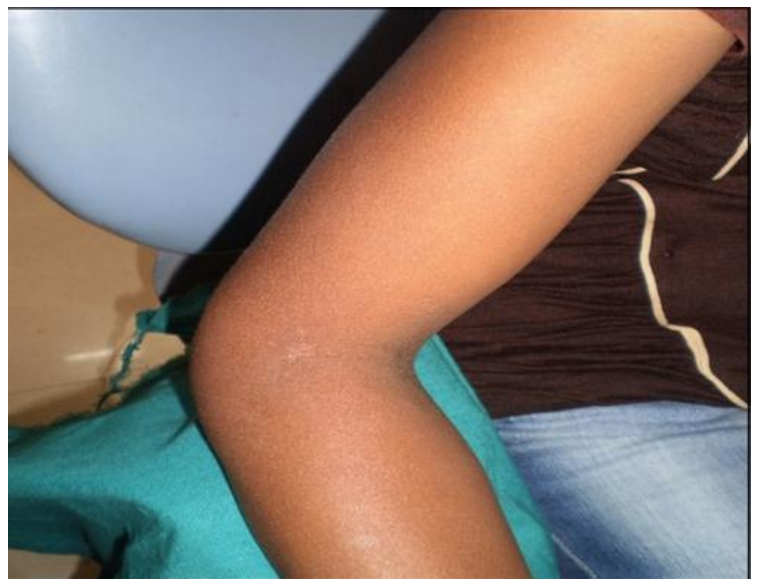

Fig. 4: Right arm showing dry skin

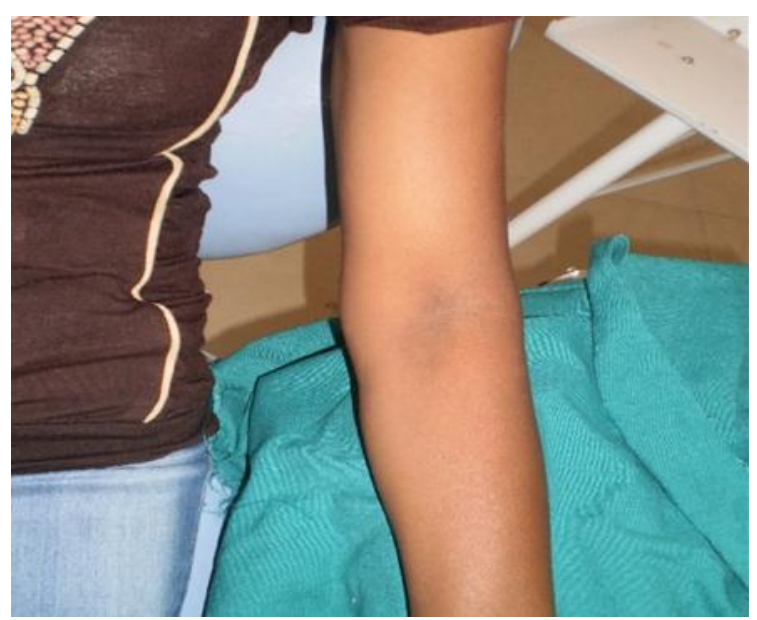

Fig. 5: Left Arm showing dry skin

\section{Discussion}

Ectodermal dysplasia is a large, heterogeneous group of inherited disorders, manifestations of which is seen in more than one ectodermal derivative. The tissues primarily affected are the skin, hair, nails, eccrine glands, and teeth. It occur approximately one in every
100,000 births. $^{3}$ It is generally due to problem in development of ectodermal derivatives in early embryonic life. The genes are located on varous chromosomes and they get mutated or deleted. Hypohidrotic ED which is $\mathrm{x}$ linked has been mapped in the proximal area of the long arm of band Xq-12q13.1. Hidrotic ED (Clouston syndrome) is due to GJB6, which encodes for connexin-30.Ectodermal dysplasia is of two types, ie. hypohidrotic form (Christ Touraine Syndrome) which is X-linked and it has the classical triad of hypodontia, hypotrichosis and hypohidrosis and the other category is the hidrotic type (Clouston Syndrome), which also affects the teeth, hair and nails sparing the sweat glands. ${ }^{4}$ Externally fine, sparse, lustreless fair hair is seen over the scalp along with extensive scaling of the skin and nonexplained pyrexia and heat intolerance most commonly occurs due to anhidrosis. Intraorally it is seen that missing permanent teeth are most commonly present. The maxillary central incisors and canines present with a conical crown form. In some instances one or both jaws may be edentulous and the alveolar processes doesn't develop due to the absence of teeth. ${ }^{5}$ Diagnosis is based on family history, clinical and radiological examination. Diagnosis in early infancy is difficult as the involving teeth, hair and inability to sweat are difficult to detect. Treatment is by providing dentures to child early as 2 years of age and due to difficulty in mastication and speech provide child with prosthetic teeth.

\section{Conclusion}

As the ectodermal dysoasia affects the teeth, hair it has to treated quickly as it affects the patients deeply on basis of appearance. It also hampers the normal body function so correct diagnosis and prompt treatment can be helpful for the successful management of the patient.

\section{Source of Funding}

None.

\section{Conflict of Interest}

None. 


\section{References}

1. Shafers oral pathology $7^{\text {th }}$ edition

2. Shafers oral pathology $7^{\text {th }}$ edition

3. Clarke A. Hypohidrotic ectodermal dysplasia. J Med Genet 1987;24:659-63.

4. Crawford PJ, Aldred MJ, Clarke A, Tso MS. RappHodgkin syndrome: An ectodermal dysplasia involving the teeth, hair, nails and palate. Oral Surg Oral Med Oral Pathol 1989;67:50-62.
5. Crawford PJ, Aldred MJ, Clarke A, Tso MS. RappHodgkin syndrome: An ectodermal dysplasia involving the teeth, hair, nails and palate. Oral Surg Oral Med Oral Pathol 1989;67:50-62.

How to cite this article: Hassan SA, Bheteja S, Arora G. Ectodermal dysplasia diagnosed in dental set up- A case report. J Nutr, Metab Health Sci, 2019;2(3):92-4. 